\begin{tabular}{c} 
International Journal of Engineering \& Technology, 7 (4.9) (2018) 226-231 \\
International Journal of Engineering \& Technology \\
WPC \\
Website: www.sciencepubco.com/index.php/IJET \\
Research paper \\
\hline
\end{tabular}

\title{
A Review Indonesian Policy on Agricultural Industrial Commodities
}

\author{
Peni Shoffiyati ${ }^{1}$, Melinda Noer ${ }^{2}$,Rahmat Syahni Z ${ }^{3}$, Asrinaldi ${ }^{4}$ \\ ${ }^{1}$ Study Program of Post-Graduate Agricultural Sciences, Andalas University \\ ${ }^{2}$ Social Economics of Agriculture Faculty of Agriculture, Andalas University \\ ${ }^{3}$ Social Economics of Agriculture Faculty of Agriculture, Andalas University \\ ${ }^{4}$ Political Science Faculty of ISIP, Andalas University \\ *Corresponding author Email : peni_rey@yahoo.com
}

\begin{abstract}
Agricultural development is defined as an integral part of economic and society development as a whole which is implemented in a planned manner. The role of the Government is as a stimulator and facilitator, so that the economic activities of farmers can be optimized albeit the many problems faced. The purpose of this study is to see how the form of agricultural development policy and its implementation on agricultural industry commodities as well as to understand the problems to improve the policies and overcome the existing problems. The method used in this study is the systematic literature review. The results of the study put forward several policies on agricultural industry commodity related to price, macroeconomic, investmentand supply chain management. Problems in agricultural development include technological, institutional, marketing and information issues. Supply chain management policy becomes the most important policy because it has a more comprehensive scope covering raw material supply management, activities among supply chain actors, pricing on each supply chain actor, to providing the necessary investment in the supply chain process. Implementers of supply chain management policies include supply chain management actors from upstream to downstream. Improvements made are shortening supply chain path by providing a meeting point of various related parties ranging from farmers as producers, intermediary traders to end consumers. The ultimate goal is expected supply chain will be shorter, travel distribution becomes faster, sharing of information, management of technology and existence of institutional network among supply chain actors.
\end{abstract}

Keywords: Agricultural Development, Policy review, Supply Chain Management.

\section{Introduction}

Development is a process of change towards something better, in the form of physical, economic, and social changes in a sustainable way in the community environment, which one physical changes related to infrastructure in the form of facilities and infrastructure in the community, while the economic changes associated with increased income to improve the lives of people (1-3). The agricultural sector has a very big role in development because it is closely related to the fulfillment of human needs. Agricultural development is defined as an integral part of economic development and society as a whole which is implemented in a planned manner. As such,agricultural development policy is very important for economic development(4-6).

The concept of agricultural development can be based on economic development by understanding the role of agriculture in economic development, the economic pattern in traditional agriculture, and the process of economic activity in agriculture which can also be an interaction between the availability of economicresources units (e.g. farming, agriculture industry and technology). Agricultural development has a strategic role in the national economy which is in line with Indonesia's development objectives in order to improve the welfare of society, accelerate economic growth, reduce poverty, provide employment, and maintain the balance of natural resources and environment (7-10).
The paradigm of agricultural development puts farmers as subjects, not solely as participants in achieving national goals. Therefore, the development of community capacity to accelerate efforts to empower the farmers' economy is at the heart of agricultural development. The effort was made to prepare the agricultural community to become independent and able to improve themselves. The role of the Government is as a stimulator and facilitator, so that socio-economic activities of the farming community can run as well as possible.

For agriculture industry commodities such as palm oil, cocoa, coffee and tea, the Government has implemented many public policies in the sub-sector of the plantation industry. The focus of the policies is generally only on the technical side of cultivation for farmers to improve the cultivation techniques which will also increase the productivity of agricultural industry commodities. The other policiesare related to the price of industrial commodities. Through the pricing policy, the government can only protect the smallholders compared to self-help farmers in some agricultural industry commodities. Infrastructure policy is also one of the other public policies that are expected to launch a supply chain distribution system from farmers (upstream) to end consumers (downstream).

As such, this study aims to see how the form of agricultural development policy and its implementation on agricultural industry commodities. 


\section{Literature Review}

\section{Agricultural Development Policy}

Agricultural policy is defined as government efforts through various instruments and regulations to increase production and consumption of agricultural commodities (11-13). Agricultural policy is also defined as a series of actions that have been, are, and will be implemented by the government to achieve certain objectives within the agricultural sector (14). The objective of agricultural policy in general is to promote agriculture and to make it more productive so that it can improve the welfare of farmers.

The general policy formulation is based on a variety of considerations including political, socioeconomic, environmental, resource, feasibility, in addition to technical factors (15). According to Pranolo (16), the policy of agricultural development in a country is influenced by external factors characterized by the openness of the economy, and free trade. External factors affecting agricultural development policy in Indonesia include international agreements, and agricultural trade policies in trading partner countries of Indonesia.

\section{Supply Chain Management}

Supply chain management is the integration between planning, coordination of all processes and business activities to deliver the value of the product's superiority to the consumers as a whole to meet the satisfaction needs of stakeholders in the supply chain system and closely related to the competitive advantage of a company, characterized to fulfillment of satisfaction consumers in terms of quality, quantity and time delivery (17). Simchi-Levi (18) defines supply chain management as an approach used to efficiently integrate suppliers, manufacturing, warehousing and storage so that goods are produced and distributed in the right quantities, in the right locations, and in the right time, in order minimization of system cost as a whole while fulfilling service of all requirement in every level.

Supply chain management is also defined as a method, tool, or approach used by its management ie companies involved in supplying raw materials, producing and delivering it to the hands of consumers based on mutually beneficial collaboration (19-20). Pujawan (20) states that supply chain is a network of companies that work together to create and deliver a product to end users. Vorst (17) \& (21), suggests that in the supply chain there are three kinds of flow that must be managed ie the flow of goods from upstream to downstream, downstream flow of money, and the flow of information either from upstream to downstream or vice versa .

Overall supply chain management is not only oriented to the internal affairs of the company, but also includes external affairs involving relationships with partner companies that are manifested in collaboration and coordination, mutually beneficial and not mutually sacrificing the interests of each individual company involved. The scope of supply chain management activities includes four parts: product development, procurement, planning and control, operations or production, and delivery or distribution (20)

\section{Methods}

Systematic literature review was used to identify, assess and interpret all findings on a research topic. Literature review contains descriptions of theories, findings and other research materials derived from reference materials to serve as the foundation of research activities and to know to what extent science-related research has evolved, to what extent conclusions and generalizations have been made so that the necessary situations obtained (22-23). The criteria for the systematic literature review consist of the following : [1] publication for years 2007 onward, [2] articles mainly indexed in minimum scopus indexed journal would be refered, and [3] subject matters related "agricultural" and "public policy" will be applied in the systematic literature review.

\subsection{Data Collection}

The data of this research are secondary data which comes from various literatures in the form of journal and text book, and other sources related to research topic. In the literature search process some search keywords are defined "agricultural" and "public policy". Selection of papers was done on publication year from 2007 until today (2018) which result in 64,933 papers. From the selection conducted based on the publication year, title match, abstract of the research topic, only 10 papers were selected as the main literature for the study.

\section{Results and Discussion}

Based on the selection of some of the literature sought, 10 main literatures were considered most relevant to the topics covered. Table 1 shows the comparison of the main literature.

Table 1. Comparison of Main Literature

\begin{tabular}{|c|c|c|c|}
\hline No & Literature & Title & Results \\
\hline 1 & (24) & $\begin{array}{l}\text { How Can Health, Agricul- } \\
\text { ture And Economic Policy } \\
\text { Actors Work Together To } \\
\text { Enhance The External } \\
\text { Food Environment For } \\
\text { Fruit And Vegetables? A } \\
\text { Qualitative Policy Analy- } \\
\text { sis In India }\end{array}$ & $\begin{array}{l}\text { Key opportunities within } \\
\text { the supply chain include } \\
\text { developing strategic } \\
\text { Public-Private Partner- } \\
\text { ships, linking health and } \\
\text { economic/agricultural } \\
\text { policy agendas, and } \\
\text { strengthening surveil- } \\
\text { lance of policy impacts } \\
\text { on consumer access to } \\
\text { fruit and vegetables. }\end{array}$ \\
\hline 2 & (25) & $\begin{array}{l}\text { Public Awareness Con- } \\
\text { cerning The Multifunc- } \\
\text { tionality of Cypriot } \\
\text { Agriculture }\end{array}$ & $\begin{array}{l}\text { Decisions about the } \\
\text { cropping pattern, rural } \\
\text { development and price } \\
\text { policies should always } \\
\text { incorporate } \\
\text { public opinions, attitudes } \\
\text { and preferences. }\end{array}$ \\
\hline 3 & (26) & $\begin{array}{l}\text { The Political Economy of } \\
\text { The Brazilian Model of } \\
\text { Agricultural } \\
\text { Development: Institutions } \\
\text { Versus Sectoral Policy }\end{array}$ & $\begin{array}{l}\text { The importance of institu- } \\
\text { tional setting inclusive and } \\
\text { sustainable creating the } \\
\text { underlying fiscal, monetary } \\
\text { and political environment } \\
\text { on the effects of agricultural } \\
\text { policy }\end{array}$ \\
\hline 4 & (27) & $\begin{array}{l}\text { Green Jobs and policy } \\
\text { Measures for a Sustainable } \\
\text { Agriculture }\end{array}$ & $\begin{array}{l}\text { The Sustainable agriculture } \\
\text { policy options analyzed for } \\
\text { intervention in sector agri- } \\
\text { culture include both finan- } \\
\text { cial and regulatory } \\
\text { measures, such as subsidies, } \\
\text { taxes, public R\&D, interna- } \\
\text { tional } \\
\text { assistance and regulated } \\
\text { standards, as well as mar- } \\
\text { keting processes. }\end{array}$ \\
\hline 5 & (28) & $\begin{array}{l}\text { How comparable are } \\
\text { cross-country data on } \\
\text { agricultural public ex- } \\
\text { penditures? }\end{array}$ & $\begin{array}{l}\text { Agricultural public ex- } \\
\text { penditures are key for de- } \\
\text { termining public resource } \\
\text { needs to } \\
\text { support food security in the } \\
\text { developing world. }\end{array}$ \\
\hline 6 & (29) & $\begin{array}{l}\text { Agricultural Policy } \\
\text { Schemes: United States' } \\
\text { Agricultural System }\end{array}$ & $\begin{array}{l}\text { Policy on import barriers, } \\
\text { export subsidy policies and } \\
\text { dairy pricing policies }\end{array}$ \\
\hline 7 & (30) & $\begin{array}{l}\text { TRANSIT - A model for } \\
\text { simulating infrastructure } \\
\text { and policy } \\
\text { interventions in agricul- } \\
\text { ture logistics: Application } \\
\text { to the northern } \\
\text { Australia beef industry }\end{array}$ & $\begin{array}{l}\text { Agricultural logistic inter- } \\
\text { vention policy in the form } \\
\text { of transportation network } \\
\text { infrastructure Strategic } \\
\text { Investment Tool (TRANS- } \\
\text { IT) }\end{array}$ \\
\hline
\end{tabular}




\begin{tabular}{|c|c|c|c|}
\hline 8 & (31) & $\begin{array}{l}\text { Analysis } \\
\text { Agricultural public policy: } \\
\text { Green or sustainable? }\end{array}$ & $\begin{array}{l}\text { Consider economic, social } \\
\text { and ecological objectives in } \\
\text { the design of agricultural } \\
\text { public policy }\end{array}$ \\
\hline 9 & (32) & $\begin{array}{l}\text { Institutional analysis of } \\
\text { food and agriculture poli- } \\
\text { cy in the Caribbean: } \\
\text { The case of Saint Lucia }\end{array}$ & $\begin{array}{l}\text { Results suggest thatrule } \\
\text { convergence in export } \\
\text { (formal) and domestic } \\
\text { (informal) agricultural } \\
\text { production systems dis- } \\
\text { placedinformal institutions } \\
\text { to a lower position in the } \\
\text { institutional hierarchy. This } \\
\text { institutional change hasre- } \\
\text { duced interactions between } \\
\text { farming community mem- } \\
\text { bers, with negative implica- } \\
\text { tions for bonding andbridg- } \\
\text { ing social capital in the } \\
\text { domestic food production } \\
\text { system. }\end{array}$ \\
\hline 10 & (33) & $\begin{array}{l}\text { The provision of public } \\
\text { goods by agriculture: } \\
\text { Critical } \\
\text { questions for effective and } \\
\text { efficient policy making }\end{array}$ & $\begin{array}{l}\text { Policy interventions in the } \\
\text { supply (demand and sup- } \\
\text { ply) of public goods: agri- } \\
\text { cultural commodities }\end{array}$ \\
\hline
\end{tabular}

Based on Table 1, the papers were found to fulfill the two requirement for systematic literature review. Upon futher analysis, two policy forms were uncovered, i.e.agricultural development policy form, and policy implementation on agricultural industrial commodities.

\subsection{Agricultural Development Policy Form}

Based on the results of the systematic literature review, some forms of agricultural development policy are as follows:

\subsubsection{Price Policy}

The agricultural commodity price policy is a specific policy applied to a single agricultural industry commodity. Price policy can also affect agricultural inputs. A common pricing policy is the tax and subsidy policy, and international trade barriers policies. Tax policies and subsidies on agricultural commodities lead to transfers between the state budget and producers and consumers. In the case of taxes, the transfer of resources flows to the interim government in terms of transfer of resources derived from the government. For example, fertilizer subsidies represent transfers from the government budget on fertilizer.

International trade barriers policies are taxes or quotas that limit import or export. Import obstacles can raise the price of agricultural commodities in the country. For example in soybean commodities, the government does not obstruct import in order to avoid the shortage of soybean needs in the manufacture of tofu and tempeh. More imports of soybeans caused the amount of imported soybeans in the country to increase so that the price is cheaper than the local price of soybeans whose price is increasing due to the less amount compared to imported soybeans. On the policy side of export barriers, for example on cocoa commodity through Minister of Finance Regulation no. 67 / PMK.011 / 2010 dated March 22, 2010 concerns the imposition of export duty on the export of cocoa beans. The objective of this policy is to ensure domestic cocoa supply for the domestic cocoa industry to flourish. The large number of exported cocoa beans appears to have caused the domestic supply of cocoa to decrease to meet the needs of the domestic cocoa industry (34).

In accordance with the existing pricing policy in Indonesia, Ragkos, et.al. (25) stated that the pricing policy is one of the aspects affecting rural development policy measures in addition to aspects of cropping pattern on certain agricultural commodities. Research (25) stated that multifunctional agriculture is a core dimension in the design of EU rural development policy. The results of (25) argued that agriculture plays many roles in the general rural development context which encompasses many aspects of environmental quality, water resources management, rural facilities, and maintenance of agricultural professions. The pricing policy on agricultural commodities is also in accordance with (33) research which mentions policy intervention in the supply (demand and supply) of public goods on agricultural commodities.

\subsubsection{Macroeconomic Policy}

Macroeconomic policy covers all regions within one country, so this policy will affect all commodities. Manufacturers and consumers of agricultural commodities will be affected by this policy even though they are not involved in this national policy-making process. There are three macroeconomic policies affecting the agricultural sector, namely fiscal and monetary policy, exchange rate policy, and domestic factor price policy. Monetary policy is defined as government control in the supply of money and then aggregate demand. When money supply rises higher than aggregate growth in goods and services, inflationary pressures will arise. Fiscal policy is concerned with a balance between government tax policies that increase government revenues and public expenditure policies that use these revenues. If government spending is greater than its revenue, then the government is experiencing fiscal deficit. This situation will cause inflation if the deficit is closed by increasing the supply of money.

The exchange rate policy directly affects output prices and agricultural production costs. The exchange rate is the value of the conversion of the domestic currency against the foreign currency. Most agricultural commodities are traded internationally and most countries import or export some of the needs or products of agricultural commodities. In internationally traded products, world prices will be equal to domestic prices in the absence of trade barriers. By itself, the exchange rate directly affects the price of agricultural products because the domestic price (valued in domestic currency) of products traded equals world prices (valued in foreign currency) multiplied by their exchange rate (ratio between domestic currency and currency foreign). Domestic factor price policy directly affects agricultural production costs. Domestic factors consist of land, labor and capital. The cost of land and labor is usually the largest portion of the cost of agricultural production in developing countries. Governments often implement macroeconomic policies that affect the value of land rent, labor wage, or interest rates prevailing throughout the country. Other domestic factor policies such as minimum wage or maximum interest rate, more affect one sector than other sectors.

The macroeconomic policy is in line with (27) study that sustainable agriculture policy is also linked to economic aspects where interventions in this aspect include financial and regulatory measures, such as subsidies, taxes, public research and development, international assistance and regulated standards, as well as the marketing process. Another study by Mogues (28) suggests that agricultural public spending is a key to determining the need for public resources to support food security in developing countries

The macroeconomic policy is also in line with (29) study which stated that dairy farming policies in the United States include border measures that create import barriers for most dairy products and export subsidies for a few manufactured dairy products, federal and state marketing orders that regulate milk prices at the processor and farm levels, government purchases of manufactured dairy products to support the farm price of milk, and income support to dairy farmers through deficiency payments.

\subsubsection{Public Investment Policy}

Public investment policy is manifested in the form of capital, infrastructure, human resources, and technology research and development. Public investment policy in the form of capital is to allocate investment expenditure (capital) sourced from the state budget (or better known as APBN in Indonesia). One of the problems faced by farmers is the difficulties and shortcomings of getting working capital. Public investment policies in the form of infra- 
structure are important capital goods, such as roads, ports, and irrigation networks to increase the income of agricultural producers or lower production costs. The capital goods are known as "public goods", whose costs are sourced from the government budget. Investment in the form of infrastructure is area-specific as well as its benefits will largely be enjoyed by producers and consumers in the region.

Public investment policies in the form of human resources include various types of government expenditures to improve the skill level or skills and health conditions of producers and consumers. Investment in the form of agricultural schools training and extension centers (or better known as BPTP and BLPP in Indonesia), Field School Activity of Agriculture is an example of public investment that can increase the human resource capacity of the agricultural sector. This kind of investment is crucial in long-term development, but the results will only be visible for a long time. Public investment policy in the form of research and technology development is another example of public goods that directly provide benefits to agricultural producers and consumers. This form of policy through agricultural research in the form of cultivation technology and agricultural processing technology.

The public investment policy is in accordance with the research of (26) which stated that long-term investment in local agricultural technology is a crucial determinant of Brazil's agricultural transformation from low productivity and backwardness to the curren status of a major player in the international market. Mueller (26) also assert that transformation is successful when inclusive and sustainable institutions can create a fiscal, monetary and political environment in which the policy can succeed.

Bianco (27) also stated that sustainable agriculture policy implements technology introduction and mechanization of agricultura operations so that agricultural productivity will increase significantly as well as improvements in transport infrastructure and facilities in reducing post-harvest losses. Thus, in the research can be identified the existence of public investment policy in the form of investment in agricultural technology and investment in transportation infrastructure and post-harvest facilities. It is also in accordance with (31) study which considers economic, social and ecological objectives in the design of public policy on agriculture. In relation to public investment policy, in (30), a TRANSIT (Transport Strategic Investment Tool) system was developed, a model for infrastructure simulation and intervention policy in agricultural logistics, which is an application of the beef industry in Northern Australia. The system is designed with the goal of infrastructure investment in roads, bridges, processing and storage, combined with policy changes having the potential to substantially reduce costs and increase the resilience of the agricultural industry.

\subsubsection{Agricultural Policy through Supply Chain Management}

The form of agricultural policy through supply chain management according to National Planning Agency or better known as (35) includes the policy of agribusiness terminal development, the policy of the trading house, the policy of the development of Processing Unit and Marketing of Agricultural Products (or better known as UP3HP in Indonesia), and the policy of Warehouse Receipt System. Agribusiness terminal development policy is the construction of a place of sale and purchase transactions between producers and traders of agricultural commodity products equipped with storage facilities, sorting, packaging and sales facilities such as exhibition hall, information center, and modern transaction system as well as accommodation facilities and convenient transportation. The objective of the agribusiness terminal development policy is to increase the added value for farmers, to educate farmers to improve their production quality, to change the mindset of the farmers towards the agribusiness mindset, and to increase the source of income. Another supply chain management policy is the establishment of a trading house in order to increase export access and the development of the marketing mix in the country that is the center of transactions / trade for agricultural commodities. The objectives of establishing a trading house of Indonesian agricultural products in several partner countries include opening and strengthening international market access for small and medium scale agricultural products, expanding and increasing the market share of large-scale agro-business products, and as an information center, promotion, and advocacy for Indonesian agricultural products in the international market.

In addition to these policies, the UP3HP development program policy conceptually is also designed to overcome the problem of linkage disparity between processing subsystem and marketing subsystem faced by business actors of agricultural processing. The purpose of the UP3HP development program is as one of the facilitation efforts for the empowerment of agricultural processing business actors in order to implement the quality management, business management, the application of appropriate technology, and facilitate access to processing facilities and capital and marketing the results. The government policy to assist farmers in facing price fluctuations is to design and facilitate the implementation of Warehouse Receipt System (or better known as SRG in Indonesia). Selling system implemented through SRG activities is one of the efforts undertaken to help farmers from the negative impact of declining prices during the harvest season. Through the delayselling system farmers are expectedto get an economical price or a reasonable price for the sustainability of its farming business. Delay-Selling system encourage farmers to sell the harvest at the time of the highest price, also as a driver to improve the quality of agricultural products.

The policy form of supply chain management pursuant to (35) is more to institutional policy in accordance with food and agriculture policy in Caribbean Saunt Lucia case in (32). The study stated that there are important roles of some institutions in the Caribbean domestic food system. There is thus a need to better identify liaison institutions in the agricultural sector, such as adaptive comanagement models, which serve to support the creation of collective rules, the sharing of power and knowledge among policy actors from different levels within the hierarchy of government. In line with the study of $(24,32)$ also makes use of actors in the supply chain management of fruits and vegetables, namely health actors to play a role in influencing agricultural policy. Thow et al. (24) identified specific opportunities for strengthening policies to increase the supply of fruit and vegetables in India along the supply chain. Public health actors play an important role in integrating agriculture policy agendas on fruits and vegetables, with health sector policy efforts to improve consumer access and demand for fruit and vegetable products.

\subsection{Policy Implementation on Agricultural Industrial Commodities}

\subsubsection{Policy on Palm Oil Commodity}

In palm oil commodities government policies include Verification or Technical Traceability to Palm Oil Exports, Crude Palm Oil (CPO) and its Derivative Products (Minister of Trade Regulation no 29/M-Dag/PER/6/2013). In addition, there is also a policy on the Collection and Use of Oil Palm Plantation Funds, where the content is set about a national strategy supported by the management of funds for the development of sustainable palm oil plantations (Presidential Decree no 61 of 2015). In addition there is a pricing policy by the Plantation Office specifically for companies that have smallholders, while for independent farmers the price of oil palm purchased adjusts these prices.

The problem that exists in the implementation of the policy is that the government only focuses on technical surveillance of the export of palm oil and/or its derivatives while the problems that occur in the field more about farmers that confuse to market their harvest if not accommodated on the palm oil industry. While the government policy on the management of oil palm plantation funds is limited to levies on exports of oil palm plantation commodities and or derivatives used for the development of human 
resources of oil palm plantations, research and development of oil palm plantations as well as the promotion and infrastructural development of oil palm plantations need to focused as well.

\subsubsection{Policy on Cocoa Commodity}

In the cocoa commodity, the government policy covers the stipulation of exported goods subject to import duty and exit fees (Minister of Finance Regulation no 67/PMK.011/ 2010). Besides, it is also regulated the policy on the enforcement of the Indonesian National Standard of Cocoa Powder Compulsory (Regulation of The Minister of Industry no 45/M-IND/PER/5/2009). The implications of the policy of a company producing or importing cocoa shall apply SNI and have SPPT-SNI issued by LSPro and affix SNI Cacao Powder marks (bulk, packaging, mix/blending and processed repacked). The other cocoa commodity policy is About the Appointment of Conformity Assessment Institution in the framework of the Compulsory Implementation/Enforcement and Supervision of Indonesian National Standard (SNI) of Cocoa (Regulation of The Minister of Industry no 143/MIND/PER/10/2009). It can be concluded that government policy has been more to the determination of export duty and tariff, SNI application for powdered cocoa production, appointment of conformity assessment body for SNI enforcement and supervision. In its implementation, the government focuses more on improving the human resources of cocoa farmers, providing assistance in the form of equipment for cocoa plantation, the effort to increase cocoa production in terms of quality improvement, cocoa development to extensification of cocoa plantation, and village funding for cocoa plantation development to business plan regions, and there is no government way to protect cocoa selling price because so far fluctuating cocoa prices are affected by dollar prices, cocoa prices are also dependent on cocoa demand and quality of cocoa due to weather and pest attacks.

\subsubsection{Policy On Coffee Commodity}

Government policy on coffee industry commodities one of them is impose income tax facility $(\mathrm{PPh})$ for new investment of coffee processing industry in some areas outside Java. In addition, the government also harmonizes tariffs on processed coffee products in the form of roasted coffee, coffee powder, instant coffee, and coffee mix from 5 percent to 20 percent (Regulation of the Minister of Finance No. 132 Year 2015). Another government policy concerning coffee industry commodities is to enforce compulsory national standards (SNI) of Coffee Instant which became effective on January 17, 2016 (Regulation of the Minister of Industry no. 87 years 2014)

\subsubsection{Policy On Tea Commodities}

Government policy on tea industry commodity is the imposition of SNI for imported tea. In addition, especially in West Sumatera where one of the locus of state-owned tea processing company is PTPN VI Danau Kembar Solok,the policy of tea purchase price from farmers as raw material determined by Jakarta Tea Auction (or better known as KPB in Indonesia) through auction process.

\section{Conclusion and Recommendation}

Based on the previous description can be proposed supply chain management policy becomes the most important than other policies. This is because the supply chain management policy has a more comprehensive scope covering supply management (raw material supply), activity among supply chain actors, price fixing on each supply chain actors, to the provision of facilities and infrastructure needed in the supply chain process . Implementation of supply chain policy is expected to shorten supply chain and shorten the time of distribution by providing a meeting point for various parties related to the supply chain from farmers as producers, intermediary traders to final consumers. The existence of sup- ply chain management policy is also aimed to make the supply chain actors can share information and technology as well as interinstitutional in the supply chain so that they can solve the existing problems. Based on comparisons with agricultural policies in other countries, agriculture policy recommendations can be recommended through an inclusive and sustainable institutional system to create a financial, monetary and political environment that is fundamental to the impact of agricultural policy

\section{Conflict of Interest}

Conflicts of interest that occurred in the implementation of agricultural commodity policy is that still exist parties who harmed ie the farmer as one of the upstream supply chain enthusiasts. Whereas this requires the attention of the government as the policy maker on how to control the implementation of agricultural policies that have been made.

\section{Acknowledgments}

On this occasion the authors express gratitude to all parties who have helped in the writing of this study.

\section{References}

[1] Asnawi, Sofyan. 1999. Development of Thought in Regional and Rural Development. Psi-Sdalp, Unand. Padang.

[2] Nasution, Zulkarnaen. 2007. Communication Application Development, Theory And Adapters. Rajawali Press. Jakarta.

[3] Roger, E.M. Dan Shoemaker, F.F., 1971, Communication Of Innovations, London: The Free Press.

[4] Mosher, Arthur Theodore . 1966. Getting Agriculture Moving. Agricultural Development Council. New York.

[5] Nicolic, V., Ivonis, M. \& Stevovic, I. 2014. Innovation Of Organization Model For Integral Rural Development - Serbia Case Study. Journal Economic Of Agriculture, 61

[6] Patra, R. 2014. Agricultural Development In Odisha : Are The Disparities Growing ? International Journal Of Food And Agricultural Economics 2, 129-144.

[7] Ministry of Agriculture. 2004. Strategic Plan of the Ministry of Agriculture Year 2005-2009. Ministry of Agriculture. Jakarta.

[8] Ministry of Agriculture. 2009. Strategic Plan of the Ministry of Agriculture Year 2010-2014. Ministry of Agriculture. Jakarta.

[9] Saragih, B. 2010. The New Paradigm of Agricultural-Based Economic Development. IPB Press. Bogor.

[10] Todaro, M.P. and S.C. Smith. 2014. Economic Development. Pearson Education Press. New York.

[11] Pearson, S., C. Gotsh and S. Bahri. 2004. Application of Policy Analysis Matrix in Indonesian Agriculture. DAI-FSPA-Yayasan Obor. Jakarta.

[12] Tongeren, Van F. 2008. Agricultural Policy Design and Implementation: A Synthesis. OECD Food, Agriculture and Fisheries Working Paper No. 7. OECD Publishing. Paris.

[13] Ragasa, C., S.C. Babu and J. Ulimwengu. 2011. Institutional and Capacity Challenges in Agricultural Policy Process. IFPRI. Melbourne.

[14] Ellis, F. 1992. Agricultural Policies in Developing Countries.Cambridge University Press. Melbourne.

[15] Aziza, T Noor. 2014. Given the Agricultural Development Policy. Field of Appraisal Apparatus PKP2A III LAN. Samarinda.

[16] Pranolo, Tito. 2000. Agricultural Development and Trade Liberalization Paper presented at Konpernas XIII Perhepi, Jakarta 12 February 2000

[17] Vorst, J. G. A. J. Van der. 2004. Supply Chain Management ; Theory and Practice. Camps, T., Diederen, P., Hofstede, G. J., Vos, B. [Editors].The Emerging World of Chains \& Networks.Hoofdtuk ; Elsevier.

[18] Simchi-Levi, D. Kaminsky, P. dan Simchi-Levi, E. 2000. Designing and Managing the Supply Chain : Concept, Strategies And Case Studies. The MSGraw-Hill Company, Inc. Singapore.

[19] Beamon BM, Chen VCP. 2001. Performance Analysis of Conjoined Supply Chains. International Journal of Production Research, 39, (14): 3195-3218.

[20] Pujawan, I. N. 2005. Supply Chain Manajemen. Guna Widya Publisher. Surabaya. 
[21] Gumus AT, Gusneri AF. 2009. A Multi-echelon Inventory Management Framework For Stochastic and Fuzzy Supply Chain. Journal Expert System With Application, 36:5565-5575.

[22] Hasibuan, Zainal A. 2007. Research Methodology In The Field Of Computer Science And Information Technology: Concepts, Techniques, And Applications. Jakarta: Faculty of Computer Science University of Indonesia.

[23] Nazir, M. 2005. Research methods. Jakarta: Ghalia Indonesia.

[24] Thow,Anne Marie, Garima Vermab, Deepa Sonib, Divya Sonib, Deepti Kumar Berib,Poorvaja Kumarb, Karen R. Siegelc,d, Nida Shaikhc,e, Shweta Khandelwalb. 2018. How Can Health, Agriculture And Economic Policy Actors Work Together ToEnhance The External Food Environment For Fruit And Vegetables? AQualitative Policy Analysis In India. Food Policy. 2018

[25] Ragkos, Athanasios, Alexandros Theodoridisb and Christos Batziosb. 2015. Public Awareness Concerning The Multifunctionality Of CypriotAgriculture. Agriculture and Agricultural Science Procedia 4 ( 2015 ) 147 - 157

[26] Mueller, Bernardo, Charles Mueller. 2016. The Political Economy Of The Brazilian Model Of AgriculturalDevelopment: Institutions Versus Sectoral Policy. The Quarterly Review of Economics and Finance 62 (2016) 12-20.

[27] Bianco, Adele. 2016. Green Jobs and policy Measures for a Sustainable Agriculture. Agriculture and Agricultural Science Procedia 8 ( 2016 ) $346-352$.

[28] Mogues, Tewodaj, Richard Anson. 2018. How comparable are cross-country data on agricultural public expenditures?Global Food Security 16 (2018) 46-53.

[29] Jesse, E. 2011. Agricultural Policy Schemes: United States' Agricultural System. $2011: 300-305$.

[30] Higgins, Andrew, Stephen McFallan, Luis Laredo, Di Prestwidge, Peter Stone. 2015. TRANSIT - A model for simulating infrastructure and policy interventions in agriculture logistics: Application to the northern Australia beef industry. Computers and Electronics in Agriculture 114 (2015) 32-42.

[31] Mouysset, L. 2014. Agricultural public policy: Green or sustainable? Ecological Economics 102 (2014) 15-23.

[32] Ville a, Arlette S. Saint , Gordon M. Hickey a, Leroy E. Phillip. 2017. Institutional Analysis Of Food And Agriculture Policy In The Caribbean:The Case Of Saint Lucia. Journal of Rural Studies 51 (2017) 198-210.

[33] Westhoek, Henk J, Koen P. Overmars, Henk van Zeijts. 2013. The provision of public goods by agriculture: Critical questions for effective and efficient policy making. Environmental Science \& Policy 32 (2013) 5-13.

[34] Tresliyana, Anggita, Anna Fariyanti, and Amzul Rifin.2015.Coconut Power Indonesia In International Market. Journal of Management \& Agribusiness, Vol. 12 No. 2, July 2015.

[35] Bappenas. 2004. Procedures for Regional Development Planning for the Acceleration of Regional Development. Directorate of Special and Disadvantaged Area Development.Bappenas. 